\title{
Pelatihan Inovasi Produk Pangan Abon Pepaya Muda di Dusun Pamagersari Desa Tanjungsari Sumedang
}

\author{
Ana Widiana ${ }^{1}$,Tri Cahyanto ${ }^{2}$, Ateng Supriyatna ${ }^{3}$, Astuti Kusumorini ${ }^{4}$, Anggita Rahmi Hafsari ${ }^{5}$, Yani \\ Suryani $^{6}$, Ucu Julita ${ }^{7}$, Ida Kinasih ${ }^{8}$, Mohamad Agus Salim ${ }^{9}$, Risda Arba Ulfa ${ }^{10}$, Ayuni Adawiyah ${ }^{11}$, Isma \\ Dwi Kurniawan $^{12}$, Rahmat Taufik MA ${ }^{13}$, Yuni Kulsum ${ }^{14}$ Adisty Virakawugi Darniwa ${ }^{15}$ \\ Jurusan Biologi, Fakultas Sains Dan Teknologi, UIN Sunan Gunung Djati Bandung \\ email: tri_cahyanto@uinsgd.ac.id
}

\begin{abstract}
Papaya is a familiar fruit in Indonesia. During this time, papaya fruit is consumed by direct eating and sold at low prices. Young papaya can be processed into a form of creative food products such as abon. The manufacturing process includes preparation of material tools, stripping, steaming for 40 minutes, thin slicing, addition of complementary spices, drying, frying, and serving. The implementation of PKM activities included the dissemination of material and the practice of making abon papaya. Based on the results of the activity, it was obtained information that the participants in the activity didn't know much about the nutrients contained in papaya fruit, even the participants had never known that papaya fruit could be processed into shredded fruit. The community service activities on the topic of making shredded papaya fruit can increase awareness, knowledge, skills, and also the motivation of the business of Pamagersari Hamlet Community in Tanjungsari Village, Sumedang.
\end{abstract}

Keywords : Pelatihan Inovasi, Produk Pangan, Abon Pepaya Muda

\section{PENDAHULUAN}

Buah-buahan dan sayur-sayuran merupakan bahan pangan sumber vitamin dan mineral. Buah dan sayur merupakan salah satu jenis komoditi hortikultura yang tersedia dalam jumlah besar dan beragam tetapi memiliki sifat yang mudah rusak dan masa simpan yang relatif singkat, oleh karena itu, perlu dilakukan suatu alternatif untuk memperpanjang masa simpan buah dan sayur tersebut. Salah satu alternatif yang dipilih dalam penelitian ini yaitu menjadi produk fruit leather (Ramli dan Faizah, 2017).

Buah pepaya merupakan komoditi hasil pertanian dengan produksi buah tahun 2015 sejumlah 840.118 ton/tahun atau sekitar $4,24 \%$ dari total produksi buah nasional. Pepaya termasuk buah yang kaya gizi, mengandung kalori, karbohidrat, protein, lemak, serat, antioksidan, vitamin A, vitamin B1, vitamin B2, vitamin B3, vitamin B5, vitamin B6, asam folat, vitamin C, vitamn $\mathrm{E}$ dan vitamin K (Ramli dan Faizah, 2017). Buah pepaya merupakan buah buni. Kulit luar buah pepaya tipis. Daging buahnya tebal dengan rongga di tengah buah dengan pola pematangannya pepaya termasuk buah klimakterik (Handayani, 2010)

Buah pepaya merupakan buah yang telah dikenal luas oleh masyarakat Indonesia. Buah ini memiliki kadar air dan nilai gizi tinggi serta rasa manis. Menurut Direktorat Jenderal Hortikultura (2007) produksi pepaya di Indonesia tahun 2006 mencapai 643451ton dengan nilai dan volume ekspor mencapai masing-masing US\$13 860 dan $11914 \mathrm{~kg}$.

Buah papaya matang biasa dikonsumsi secara langsung dan buah papaya yang masih mentah bisa dijadikan sebagai bahan rujak dan dijadikan lalapan. Karena buah papaya yang sangat melimpah namun cara mengonsumsinya yang sedikit maka perlu dilakukan inovasi produk olahan berbahan dasar buah papaya. Buah papaya muda ini dapat dijadikan sebagai bahan dasar pembuatan abon nabati.

Abon merupakan produk yang berasal dari lauk-pauk kering berbentuk khas dengan bahan baku pokok berupa daging atau ikan. 
Pengolahan abon dilakukan dengan cara direbus, dicabik-cbik, dibumbui, digoreng, dan dipres. Abon umumnya memiliki komposisi gizi yang cukup baik dan dapat dikonsumsi sebagai makanan ringan atau sebagai lauk-pauk. Abon sebagai salah satu bentuk produk olahan kering sudah dikenal masyarakat luas karena harganya (Agustin, 2018). Dalam tulisan ini bahan utama abon diganti menggunakan bahan nabati berupa buah papaya muda.

Masyarakat Sunda berada dalam lingkungan yang kaya dan subur, dan memiliki keterkaitan kuat dengan alam lingkungannya. Keterikatan masyarakat Sunda dengan alam lingkungannya tampak misalnya dalam pemanfaatan alam untuk memproduksi, mendistribusi dan mengkonsumsi makanan sebagai pemenuhan kebutuhan individu, keluarga, sosial dan budayanya (Marta dkk, 2018). Hal ini juga tampak pada sebuah dusun, yaitu Dusun Pamagersari yang berada di wilayah Tanjungsari, Kabupaten Sumedang Jawa Barat.

Kabupaten Sumedang meupakan salah satu daerah strategis dalam jalur mobilisasi karena berada di antara dua kota besar Bandung dan Cirebon. Kabupaten Sumedang mengalami pertumbuhan jumlah penduduk dan pertumbuhan ekonomi yang baik serta memiliki sumber daya potensial dalam pembangunan. Kabupaten Sumedang merupakan salah satu penyumbang sektor pertanian bagi perekonomian Jawa Barat dan lokasi berdirinya berbagai perguruan tinggi terkemuka sebagai tempat investasi sumber daya manusia. Pada tahun 2014, perekonomian Kabupaten Sumedang mengalami perlambatan dibandingkan pertumbuhan tahun-tahun sebelumnya. Laju pertumbuhan PDRB Sumedang tahun 2014 mencapai 4,70 persen, sedangkan tahun 2013 sebesar 4,84 persen. Perlambatan laju pertumbuhan disebabkan karena pengaruh menurunnya produksi pertanian terutama tanaman bahan makanan terutama tanaman padi. Cuaca dan kekeringan yang panjang sebagai penyebab rendahnya produksi padi (Djuwendah, 2016).

Melihat permasalahan dan potensi yang ada, masyarakat Dusun Pamagersari Desa
Tanjungsari Sumedang dinilai perlu mengetahui lebih dalam mengenai cara pengolahan abon buah pepaya ini. Penyampaian pengetahuan yang baik kepada masyarakat dapat terlaksana melalui program pengabdian kepada masyarakat (PKM). Selain penyampaian materi pembuatan abon pepaya bagi kesehatan, kegiatan PKM ini dilengkapi dengan praktik pembuatan produk tersebut secara langsung. Dengan memberikan pengetahuan-pengetahuna tersebut kepada masyarakat diharapkan masyarakat dapat meningkatkan derajat kesehatan dan ekonomi secara mandiri.

\section{METODE PELAKSANAAN}

Kegiatan ini dilaksanakan pada tanggal 02 Mei 2019 di lokasi Dusun Pamagersari RT 05 RW 04 Desa Tanjung Sari, Sumedang. Bahan yang digunakan dalam pelatihan yaitu papaya muda, tempe, ketumbar, jinten, bawang merah, bawang putih, minyak goreng, kemiri, gula merah, dan air bersih. Alat yang digunakan dalam pelatihan ini yaitu parut, saringan, baskom, pisau, blender, dan nampan.

Pepaya muda dikupas dan dibuang bagian kulit luar, kemudian dicuci dan dikukus selama 40 menit. Pepaya muda yang telah dikukus kemudian diiris tipis-tipis memanjang kemudian ditimbang sesuai dengan berat yang diinginkan. Tempe kedelai dibagi menjadi 2 bagian, 1 bagian dikukus dan bagian yang lain tidak dikukus. Kemudian kedua-duanya dikeringkan dan digiling sampai halus menghasilkan tepung tempe kedelai. Bumbu-bumbu yaitu bawang putih, ketumbar, jintan, kemiri, gula merah dan garam digoreng tanpa minyak (digongso) di wajan di atas kompor dengan nyala api kecil. Setelah aroma bumbu tercium maka irisan nangka muda yang telah ditimbang dimasukkan ke dalam wajan. Tepung tempe dimasukkan sesuai dengan takarannya msing-masing yaitu $500 \mathrm{~g}$ dan diaduk merata. Diberi minyak goreng lalu dimulai tahap penggorengan. Minyak goreng dipanaskan, 
adonan lalu digoreng. Jika pepaya muda mulai berwarna kecoklatan dengan bentuk seperti abon daging, proses penggorengan dihentikan. Abon kemudian dikeringkan. Proses pengeringan dilakukan dengan dipanaskan dibawah panas matahari menggunakan wadah yang luas. Bawang merah yang sudah dirajang digoreng sampai berwarna kecoklatan dan kering, kemudian dicampurkan pada abon nangka muda. Abon kemudian dikemas sesuai dengan penggunaan, untuk dipasarkan.

Pelaksanaan kegiatan dilakukan dalam dua tahap yaitu: (1) Tahap Penyuluhan. Tahap awal kegiatan dimulai dengan pemberian penyuluhan mengenai mocaf dan

\section{HASIL DAN PEMBAHASAN}

\section{A. Survei Lokasi dan Potensi Dusun}

Pengabdian Kepada Masyarakat di Dususn Pamagersari Tanjungsari Sumedang diawali dengan kegiatan survei lokasi untuk mengetahui kondisi dusun, keadaan masyarakat, dan potensi dusun yang dapat dioptimalkan untuk dilakukan pendampingan. Menurut Widyasanti (2016) mengatakan survei dan penjajagan potensi desa dilakukan untuk mendapatkan data mengenai upaya pemanfaatan komoditas lokal berserta permasalahan kedua desa.

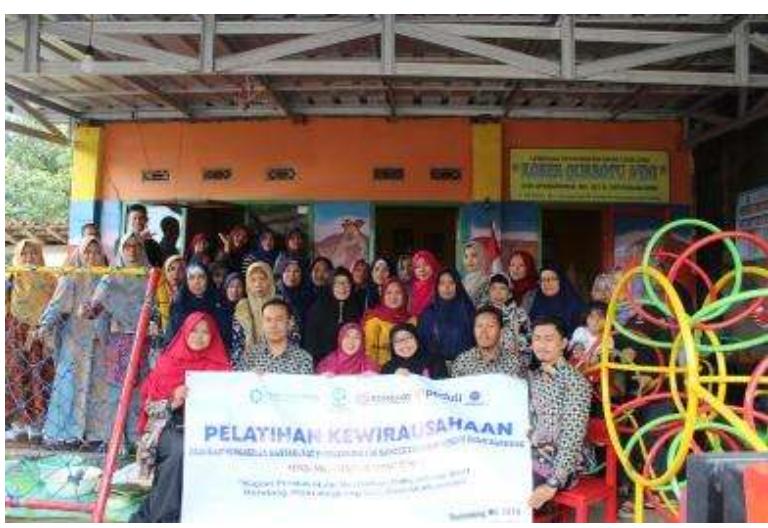

\section{B. Pelatihan Pembuatan Abon Buah Pepaya Muda}

Biologi sebagai ilmu tentang makhluk hidup berhubungan erat dengan kehidupan manfaat mocaf bagi kesehatan kepada pesertapotensi lokal yang dapat dijadikan sebagai olahan pangan kreatif; (2) Tahap Pelatihan. Tahap kedua yaitu pemberian latihan pembuatan abon buah papaya.. Pada tahap ini peserta diberikan kesempatan untuk melakukan praktik pembuatan dan pengolahan produk abon buah papaya yang dijelaskan menggunakan metode demonstrasi secara berkelompok yang didampingi oleh satu instruktur perkelompok. Di akhir kegiatan dilakukan evaluasi untuk mengetahui tingkat pemahaman peserta terhadap materi yang telah disampaikan melalui sesi tanya jawab.

\section{Gambar 1. Foto Lokasi PKM di Dusun \\ Pamagersari (Sumber: doc. 2019)}

Lokasi Dusun terletak cukup jauh dari pusat Desa Tanjungsari dengan akses yang tidak mudah. Mayoritas masyarakat bekerja sebagai buruh di tempat industri, buruh harian lepas, dan ibu rumah tangga. Setelah dilakukan wawancara, kebutuhan masyarakkat terutama segmentasi pada ibuibu mengharapkan dapat memiliki penghasilan tambahan dengan produk yang mudah dan tidak banyak mengeluarkan modal. Adapun potensi dari dusun Pamagersari adalah tanaman sayur lokal seperti tanaman singkong, tanaman papaya, sereh, dan lain sebagainya yang banyak ditemukan di kebun atau pekarangan masyarakat. Berdasarkan potensi lokal dari Dusun Pamagersari tersebut maka dibuatlah topik pelatihan produk pangan kreatif dengan memilih bahan baku buah papaya muda yang diolah menjadi abon pepaya untuk dikonsumsi maupun dikomersilkan oleh masyarakat.

sehari-hari salah satunya berkaitan dengan interaksinya dengan tumbuhan. Biologi sebagai ilmu yang berkembang bukan sekedar untuk pengetahuan saja, namun 
harus memiliki kebermaknaan aplikasinya dalam kehidupan sehari-hari dalam kehidupan masyarakat. Salah satu objek biologi yang banyak dimanfaatkan adalah tumbuhan sebagai bahan pangan seperti buah pepaya.

Buah papaya merupakan komoditas tanaman yang organ tumbuhannya banyak dimanfaatkan sebagai bahan pangan seperti bagian daun, bunga, dan terutama buahnya. Saat ini dalam mengonsumsi buah papaya masih sebatas dengan cara konsumsi secara langsung tanpa pengolahan. Banyak petani yang menjual buah papaya dengan nilai jual murah. Padahal setiap bahan pangan apabila diolah secara kreatif dapat menghasilkan makanan dengan cita rasa lebih baik dan bahkan dapat meningkatkan nilai jual bahan pangan tersebut.

Buah-buahan dan sayur-sayuran tidak selalu harus dikonsumsi dalam bentuk segar, sebagian besar diolah menjadi berbagai bentuk dan jenis makanan. Pengolahan ini bertujuan untuk memperpanjang masa simpan, meningkatkan penganekaragaman produk dan menambah nilai ekonomis (Pandiangan dkk, 2017). Salah satunya, pengolahan buah papaya menjadi abon merupakan pilihan yang tepat untuk mengonsumsi bahan pangan dengan cara yang berbeda.

Pemilihan buah papaya sebagai bahan dasar pembuatan abon ditinjau dari segi nutrisi cukup baik untuk dipertimbangkan. Menurut Bakar dan Ratnawati (2017) buah papaya ini kaya akan berbagai nutrisi didalamnya sebagaimana yang dituangkan dalam table berikut ini.

Tabel.1 Kandungan Nutrisi Buah Pepaya Mentah

\begin{tabular}{|l|c|}
\hline $\begin{array}{c}\text { Kandungan Gizi } \\
\text { (Nutrisi) }\end{array}$ & Jumlah \\
\hline Kalori & $46,00 \mathrm{Kal}$ \\
\hline Protein & $0,50 \mathrm{~g}$ \\
\hline Lemak & $-\mathrm{g}$ \\
\hline Karbohidrat & $12,20 \mathrm{~g}$ \\
\hline Kalori & $46,00 \mathrm{Kal}$ \\
\hline Protein & $0,50 \mathrm{~g}$ \\
\hline
\end{tabular}

\begin{tabular}{|l|c|}
\hline Posfor & $12,00 \mathrm{mg}$ \\
\hline Zat Besi & $1,70 \mathrm{mg}$ \\
\hline Vitamin A & $365,00 \mathrm{~S} . \mathrm{I}$ \\
\hline Vitamin & BI $0,004 \mathrm{mg}$ \\
\hline Vitamin C & $78,00 \mathrm{mg}$ \\
\hline Air & $86,70 \mathrm{mg}$ \\
\hline Calcium & $23,00 \mathrm{mg}$ \\
\hline
\end{tabular}

Buah papaya dapat dijadikan olahan pangan salah satunya menjadi abon. Menurut Sigit (2017) abon merupakan makanan yang biasanya berbahan dasar daging ayam atau daging sapi. Tapi kandungan nutrisi yang ada pada daging tersebut bisa diganti dengan memanfaatkan bahan alami seperti buahbuahan maupun sayuran. Abon adalah suatu jenis makanan kering berbentuk khas, dibuat dari daging yang direbus, disayat-sayat, dibumbui, digoreng, dan dipres. Pada umumnya masyarakat lebih mengenal abon daging sapi daripada abon daging ayam. Namun abon daging sapi dan ayam harganya tergolong mahal, sehingga dibuatlah produk menggunakan buah papaya.

Kegiatan pengabdian dilaksanakan tanggal 02 Mei 2019 dengan pemberian materi pertama yaitu mengenai tata cara pembuatan produk abon pepaya yang disampaikan dengan metode ceramah dan materi kedua yaitu praktik cara pembuatan abon pepaya yang dilakukan dengan metode demonstrasi. Materi pertama disampaikan meliputi pengenalan produk pangan halal, potensi lokal, manfaat buah pepaya bagi kesehatan pencernaan, dan tata cara pengolahan abon papaya. Selain itu juga disampaikan potensi buah papaya muda yang dapat dikembangkan menjadi produk abon papaya sampai bisa menjadi produk komersil. 


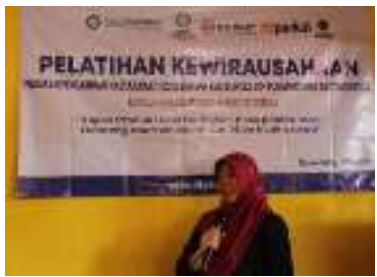

\section{Gambar 2. Tahap Penyampaian Materi Penyuluhan (Sumber: doc. 2019)}

Berdasarkan hasil kegiatan diperoleh informasi bahwa ibu-ibu perserta kegiatan belum banyak mengetahui mengenai kandungan nutrisi yang ada dalam buah papaya, bahkan ibu-ibu belum pernah mengetahu bahwa buah papaya dapat diolah menjadi abon. Meskipun telah banyak produk abon beredar di pasaran, semua peserta menuturkan belum pernah mengkonsumsi produk abon berbahan dasar buah papaya muda dan tidak mengetahui bagaimana proses pembuatannya. Selain itu, para peserta juga belum mengetahui bahwa singkong dapat diolah menjadi tepung mocaf. Selama ini ibu-ibu rumah tangga hanya mengonsumsi buah papaya muda sebagai lalapan, rujak, dan disayur. Pemberian informasi baru mengenai pengolahan buah papaya muda menjadi abon berhasil meningkatan antusias peserta selama proses diskusi sesi pertama. Hal ini dibuktikan dengan banyaknya peserta yang mengajukan pertanyaan mengenai materi yang telah disampaikan.

Penyampaian materi mengenai tata cara pembuatan abon buah pepaya meliputi alat dan bahan yang digunakan serta tahapan dalam proses pembuatan abon buah pepaya. Proses pembuatan tepung mocaf menggunakan bahan yang relatif mudah ditemukan di lingkungan tinggal para peserta sehingga memungkinkan bagi peserta untuk mempraktikan informasi yang telah diperoleh di rumah masing-masing. Begitu juga dengan peralatan yang digunakan selama proses pembuatan merupakan peralatan yang umumnya telah dimiliki oleh peserta di rumah masing-masing. Praktik pembuatan tepung mocaf oleh peserta semakin mudah setelah dilakukan sesi diskusi. Dalam kegiatan praktik ini terlihat para peserta sangat antusias menerima informasi dan terlihat keinginan kuat dari mereka untuk mencoba membuat sendiri tepung mocaf tersebut.

Setelah dibekali materi awal mengenai abon buah papaya muda. Peserta pelatihan diajak untuk mempraktikan secara berkelompok membuat produk abon buah papaya dari mulai persiapan alat bahan, proses pengolahan, dan samapi membentuk produk akhir. Setiap peserta terlihat antusias dan memiliki peran yang sama dalam kelompok untuk membuat olaha abon papaya agar menghasilkan abon terbaik. Setiap kelompok ditemani oleh satu pemandu untuk memastikan agar setiap tahap proses pembuatan abon papaya dilakukan secara benar.

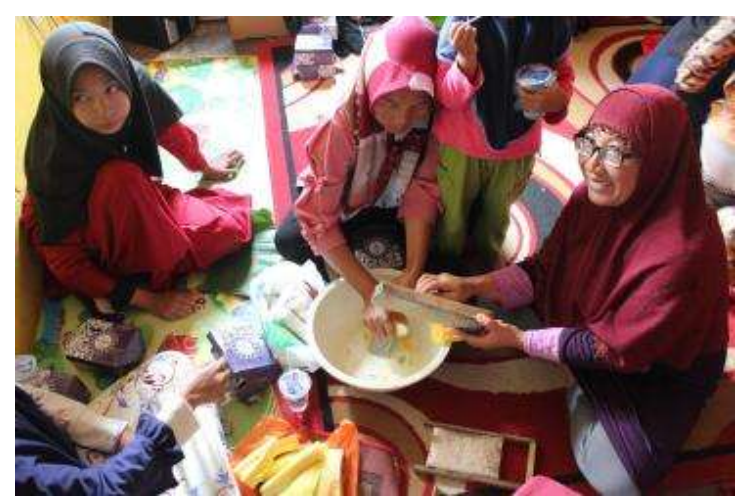

Gambar 3. Praktik Pembuatan Abon Pepaya oleh Peserta Pelatihan (Sumber: doc. 2019)

Selain bahan dasar yang mudah ditemukan, proses pembuatan abon papaya pun cukup mudah dilakukan. Sehingga pada saat peserta pelatihan praktik melakukan pembuatan abon papaya, prosesnya cukup lancar sampai selesai. Setelah produk abon papaya sudah jadi, peserta pelatihan secara bersama-sama mencicipi produk olahan baru dan hasilnya memberikan stimulus kepada masyarat untuk dapat mengolah bahan dasar potensi lokal menjadi produk makanan olahan kreatif lain. Masyarakat sadar untuk memenuhi kebutuhan bahan pangan yang bercita rasa tinggi tidak harus mahal, bahkan sebenarnya apabila kita terbuka terhadap potensi sekitar kita maka bisa dijadikan 
sebagai sesuatu yang memiliki nilai jual yang jauh lebih tinggi dari harga jual mentah. Contohnya pada olahan abon buah papaya ini.

\section{KESIMPULAN}

Kegiatan Pengabdian Kepada Masyarakat dengan topik pembuatan abon buah papaya ini dapat meningkatkan kesadaran, ilmu pengetahuan, keterampilan, dan juga motivasi usaha masyarakat Dusun Pamagersari Desa Tanjungsari Sumedang. Peserta pelatihan terutama kelompok ibu-ibu telah mengikuti serangkaian kegiatan pembuatan abon buah pepaya secara antusias.

\section{REFERENSI}

Agustin, Rani. 2018. Pengaruh Penambahan Pepaya (Carica Papaya L.) Terhadap Kualitas Abon Ayam (Gallus Gallus Domestica). Skripsi. Fakultas Tarbiyah Dan Keguruan Universitas Islam Negeri Raden Intan Lampung

Bakar, Basri A, dan Ratnawati. 2017. Petunjuk Teknis Budidaya Pepaya. Balai Pengkajian Teknologi Pertanian Aceh.

Bunyamin, U. Prajogo, Istutik, dan E.D. Yuniawati. (2016). Pemanfaatan Ubi Kayu Menjadi Tepung Mocaf untuk Pemberdayaan Masyarakat di Kecamatan Pitu Kabupaten Ngawi. Difusi Iptek, Jurnal Ilmiah Pengabdian Kepada Masyarakat, 1 (1): 1-10

Djuwendah, Endah. 2016. Analisis Potensialitas Ekonomi Dan Ketimpangan Wilayah Di Kabupaten Sumedang. Paspalum : Vol IV(1)

Handayani, Tri Lestari. 2010. Pengaruh Penyerbukan Terhadap Kualitas Buah Pepaya Betina Genotipe Ipb 1. Departemen Agronomi Dan Hortikultura Fakultas Pertanian Institut Pertanian Bogor
Marta, D.C.P, Tubagus Chaeru Nugraha dan Riza Lupi Ardiati. 2018. Kontribusi Pemanfaatan Ubi Jalar sebagai Produk Lokal Desa Sayang, Kabupaten Sumedang terhadap Peningkatan Ekonomi Kreatif Masyarakat Setempat. Jurnal Pengabdian Kepada Masyarakat. Vol 2 (12)

Pandiangan, A, Faizah Hamzah dan Rahmayuni. 2017. Pembuatan Selai Campuran Buah Pepaya dan Buah Terung Belanda. JOM Fakultas Pertanian, Vol 4(2)

Ramli, Redi Dan Faizah Hamzah. 2017. Pemanfaatan Buah Pepaya (Carica Papaya L.,) Dan Tomat (Lycopersicum Esculentum Mill.,) Dalam Pembuatan Fruit Leather. Jom Faperta. Vol. 4 (1)

Sigit, Miarsono, Mubarak Akbar, Lisa Fianti. 2017. Kualitas organoleftik Abon Ayam yang diberi Perlakuan Substitusi Kacang Tanah (Arachis hypogaea L.). Jurnal Fillia Cendekia Vol. 2 No. 1

Widyasanti, Putri, S.H. Dan Dwiratna. S.N.P. 2016. Aupaya Pemberdayaan Masyarakat Melalui Pelatihan Pembuatan Produk Sabun Berbasis Komoditas Lokal Di Kecamatan Sukamantri Ciamis. Dharmakarya: Jurnal Aplikasi Ipteks Untuk Masyarakat. Vol 5(1) 